\title{
Review \\ Vitamin D Immune-Mediated Responses and SARS-CoV-2 Infection: Clinical Implications in COVID-19
}

\author{
Emanuele Gotelli (D), Sabrina Paolino, Stefano Soldano and Maurizio Cutolo *(D) \\ Laboratory of Experimental Rheumatology and Academic Division of Clinical Rheumatology, \\ Department of Internal Medicine and Specialties (DIMI), University of Genova, IRCCS San Martino Polyclinic, \\ 16132 Genova, Italy; emanuele.gotelli@live.it (E.G.); sabrina.paolino@unige.it (S.P.); \\ stefano.soldano@unige.it (S.S.) \\ * Correspondence: mcutolo@unige.it; Tel.: +39-010-353-7994; Fax: +39-010-353-8885
}

check for updates

Citation: Gotelli, E.; Paolino, S.; Soldano, S.; Cutolo, M. Vitamin D Immune-Mediated Responses and SARS-CoV-2 Infection: Clinical Implications in COVID-19. Immuno 2022, 2, 1-12. https://doi.org/ 10.3390/immuno2010001 Academic Editor: Sylviane Muller Received: 29 November 2021 Accepted: 22 December 2021 Published: 24 December 2021 Publisher's Note: MDPI stays neutral with regard to jurisdictional claims in published maps and institutional affiliations.

Copyright: (C) 2021 by the authors. Licensee MDPI, Basel, Switzerland. This article is an open access article distributed under the terms and conditions of the Creative Commons Attribution (CC BY) license (https:// creativecommons.org/licenses/by/ $4.0 /)$.

\begin{abstract}
Active vitamin D is a true steroid hormone with pleiotropic biological effects that go beyond the classical concept of bone metabolism regulation. In fact, adequate serum levels of 25-hydroxyvitamin $\mathrm{D}(>40 \mathrm{ng} / \mathrm{mL}$ ) are required to support several biological functions, including the control of innate and adaptive immunity in course of infectious, inflammatory and autoimmune diseases. SARS-CoV-2 is responsible for the COVID-19 pandemic and deficient/insufficient serum levels of 25-hydroxyvitamin D are reported in very large cohorts of patients. Of note, vitamin D is involved in different pathophysiological processes, such as expression of SARS-CoV-2 receptor (ACE2), activation of innate (neutrophils with their extracellular traps, monocytes/macrophages, dendritic cells, natural killer cells) and adaptive (T and B lymphocytes) immune cells and clinical manifestations, such as coagulation/thrombotic disorders and acute respiratory distress syndrome. Randomized clinical trials regarding vitamin D supplementation in COVID-19 patients have shown favorable effects on the control of inflammation markers, arterial oxygen saturation/inspired fraction of oxygen ratio, admission to hospital intensive care units and mortality. A target of serum 25-hydroxyvitamin D > $50 \mathrm{ng} / \mathrm{mL}$ has been identified as protective for the course of COVID-19, potentially playing an ancillary role in the treatment of the disease.
\end{abstract}

Keywords: vitamin D; neuroendocrine immunology; coronavirus disease-19 (COVID-19); innate immunity; adaptive immunity

\section{Introduction}

Vitamin D is a steroid hormone (hormone D) that exerts pleiotropic functions in the regulation of innate and adaptive immunity [1]. Its role has been deeply investigated in recent years, with special regard to infectious and autoimmune/inflammatory diseases [2].

Inadequate serum levels of 25-hydroxyvitamin D [25(OH)D] are associated with a higher susceptibility and a worse course of viral infections of the respiratory tract (i.e., Influenza virus, Rhinovirus, Respiratory Syncytial Virus and others), tubercular infection and chronic diseases (i.e., rheumatoid arthritis, systemic lupus erythematosus, systemic sclerosis, type 2 diabetes mellitus, multiple sclerosis) [3-9].

It is therefore not surprising that vitamin D aroused great interest in managing SARSCoV-2 infection and consequent Coronavirus disease-19 (COVID-19) [10].

According to the search engine PubMed ${ }^{\circledR}$, about nine hundred papers have been published on this topic since the wide spread of the COVID pandemic infection up to 15 November 2021. In addition to the initial speculations about the involvement of vitamin D deficiency in COVID-19 susceptibility and prognosis, the results of the first randomized controlled trials (RCTs) on the therapeutic effects of vitamin D supplementation seem very promising [11-17].

In this narrative review we will discuss the effects of vitamin $D$ on the immune response in patients affected by COVID-19, with the resulting clinical implications. 


\section{Synthesis and Metabolism of Vitamin D}

Vitamin $\mathrm{D}$ can be of vegetable (vitamin $\mathrm{D}_{2}$-ergocalciferol) or animal origin (vitamin $\mathrm{D}_{3}$-cholecalciferol) [18]. The main food sources of vitamin $\mathrm{D}_{2}$ are mushrooms and yeasts, while main food sources of vitamin $\mathrm{D}_{3}$ are cereals, dairy products, fish oil and egg yolk [18].

However, the greater part of cholecalciferol (about $80 \%$ ) for human needs derives from the photochemical conversion of 7-dehydrocholesterol to pre-vitamin $\mathrm{D}_{3}$ in the outermost layer of the skin by ultraviolet $B$ sun rays [19].

Following isomerization processes, pre-vitamin $\mathrm{D}_{3}$ and ergocalciferol are converted into cholecalciferol that circulates in the bloodstream bound to Vitamin D-Binding Protein (VBP), an $\alpha$-globulin of hepatic production [20]. In the liver, cholecalciferol is hydroxylated in position 25 by hepatocyte mitochondrial and microsomal enzymes (CYP2R1 or CYP27A1). The resulting metabolite, $25(\mathrm{OH}) \mathrm{D}$ (calcifediol) is the most frequent circulating and storage form of vitamin $\mathrm{D}_{3}$ (half-life of about two-three weeks) [19]. The final hydroxylation in position 1 occurs in the kidneys by 1-alpha-hydroxylase enzyme (CYP27B1) and it is necessary for the conversion into the biologically active 1,25-dihydroxyvitamin $\mathrm{D}_{3}$ or $1,25(\mathrm{OH})_{2} \mathrm{D}_{3}$ (calcitriol) [19].

Calcitriol is a hormone (hormone D) rather a vitamin in the strict sense, since, as discussed above, it can be endogenously synthesized from cutaneous cholesterol after a cascade of metabolic processes and because it shares a cyclo-pentano-perhydro-phenantrene ring with adrenal and gonadal hormones [19].

The enzyme CYP27B1 is mainly expressed by the cells of the proximal convoluted tubule, where it is subjected to tight regulation by serum concentrations of calcium, phosphate and parathyroid hormone, but it is also expressed by neutrophils, monocytes/ macrophages, dendritic cells, $\mathrm{T}$ helper cells, keratinocytes and placental trophoblast [21]. Thus, renal calcitriol mainly exerts endocrine activities relating to bone health (regulation of the calcium-phosphorus metabolism), while peripheral calcitriol, synthesized by immune cells, has autocrine and paracrine activities in the target tissues that are additional to the hormonal effects of calcitriol produced by the kidneys [22,23].

Calcitriol then exerts its biological effects binding to the vitamin D receptor (VDR), which is widely expressed in human tissues and belongs to the nuclear receptor superfamily and to the subfamily that includes thyroid hormone receptors, retinoid receptors and peroxisomal proliferator-activated receptors [24]. After proper stimulation, VDR binds to specific DNA sequences forming a heterodimer with the retinoid $\mathrm{X}$ receptor and other co-receptors: the final result is the activation or the repression of thousands of target genes. Non-genomic effects of calcitriol in bones and muscles are mediated by the interaction between VDR and integral proteins of capacitive calcium entry in cell wall caveolae, thus inducing a rapid increase in intracellular calcium ion levels [25].

The main route of inactivation of calcitriol is additional hydroxylation by the 25-hydroxyvitamin $\mathrm{D}_{3}$-24-hydroxylase, expressed in most tissues and stimulated by the calcitriol itself, according to a rapid self-regulation circuit (half-life of 4-8 h) [26]. The polar metabolites of calcitriol are then excreted in the bile and partially reabsorbed through the enterohepatic circulation before fecal elimination [19].

\section{SARS-CoV-2 Infection and COVID-19}

SARS-CoV-2 belongs to the family of Coronaviridae, viruses that have RNA nucleic acid, helical symmetry, dimensions between 80 and $230 \mathrm{~nm}$ and a lipid envelope whose appearance in electron microscopy recalls the solar crown for the presence of rounded or petal-shaped protrusions (spikes or protein $S$ ) that branch off from the glycoproteic envelope (E) [27]. Spikes are divided in two different subunits $\left(S_{1}\right.$ and $\left.S_{2}\right)$, that are pivotal for human cells entry. There are also a hemagglutinating and complement-fixing antigen, a membrane glycoprotein $(\mathrm{M})$ and a nucleocapsid protein $(\mathrm{N})$ [27].

SARS-CoV-2 is transmitted through respiratory droplets from person to person and spike proteins interact and bind to human cells, through cell receptors such as CD26, CD147, CD209 and, above all, type 2 angiotensin-converting enzyme (ACE2) [28]. ACE2 is 
widely distributed in the human body, and in particular in the respiratory tract [29]. As a consequence, nasal epithelial cells are the first target of viral droplets in the majority of cases. $S_{1}$ subunit of the receptor-binding domain (RBD) is responsible for the attachment to ACE2, while $S_{2}$ subunit allows the fusion of viral and human cells membranes, taking advantage of host transmembrane protease serine-protease-2 (TMPRSS-2) and ADAM metallopeptidase domain 17 (ADAM17) [29].

After an endocytic process, SARS-CoV-2 definitively enters the cell and releases its RNA nucleic acid, which will be replicated by the host and spread out by exocytosis in order to infect other cells, allowing viral survival [30]. SARS-CoV-2 can exert both a direct and undirect cytopathic effect against host cells, through the recruitment of innate immunity cells and the release of inflammatory mediators [30].

These pathophysiological processes become clinically evident after a few days from viral invasion with malaise, coryza-like symptoms, low-grade fever, arthralgias and myalgias and they correspond to the early stage of the infection [31].

COVID-19 usually ends in this phase, thanks to innate immunity (the mechanisms of which are discussed in dedicated paragraph), with an excellent prognosis for the patients. However, in twenty percent of cases, SARS-CoV-2 spreading is not interrupted in the upper airways and reaches the lower respiratory tract, in particular type II pneumocytes, causing intense lung inflammation and dysregulation of surfactant production [31]. In this pulmonary phase of COVID-19, patients suffer from dyspnea and hypoxia, due to lung interstitial involvement and parenchymal damage.

Nevertheless, recovery is still possible over two weeks, thanks to activation of adaptive immunity ( $\mathrm{T}$ and $\mathrm{B}$ cells) [31,32]. Unfortunately, a minority of patients evolve to systemic hyperinflammation, caused by the so-called "cytokine storm", an exaggerated inflammatory response due to persistent viral stimulation with elevated circulating levels of interleukin (IL)-1, IL-2, IL-6, Monocyte Chemoattractant Protein-1, Macrophage Inflammatory Protein1A, Tumor Necrosis Factor- $\alpha$ (TNF- $\alpha$ ) and others [33]. This harmful cocktail of cytokines also triggers severe coagulative disorders that aggravate multiorgan failures. As expected, this condition is often lethal and requires aggressive hospital management [31].

\section{COVID-19 and Vitamin D}

Since the wide spread of the first pandemic wave of COVID-19, inadequate serum levels of 25(OH)D have been observed in affected patients, in comparison with healthy controls [34-36]. Hence, several studies investigated the correlation between vitamin D deficiency (less than $20 \mathrm{ng} / \mathrm{mL}$ )/insufficiency (between 20 and $30 \mathrm{ng} / \mathrm{mL}$ ) and risk of SARS-CoV-2 infection, course of disease, lung involvement and final outcome. Of note, even if reports have not always been totally in agreement [37], the most robust evidence (systematic reviews and meta-analysis of thousands of patients) show that low serum levels of $25(\mathrm{OH}) \mathrm{D}$ correlate with higher risk of COVID-19 [38,39] and rates of hospital admissions, longer hospital stay [40], more severe lung involvement [41] and higher mortality [42,43] than normal 25(OH)D status.

The reasons that can explain these observations are manifold and are discussed below.

\section{ACE2 Pathway Dysregulation and Vitamin D}

ACE2 is a key enzyme in the regulation of the renin-angiotensin-aldosterone system [44]. In conditions of renal hypoperfusion, juxtaglomerular cells secrete renin, a proteolytic enzyme responsible for the conversion of angiotensinogen, a glycoprotein released by the liver, into angiotensin I (Ang I). Ang I does not exert any biological activity, being the precursor of angiotensin II (Ang II).

The ACE enzyme catalyzes the conversion of Ang I into Ang II at the pulmonary capillaries level. Ang II interacts with Ang II receptor type 1 ( $\mathrm{AT}_{1}$ receptor) and mediates not only the increase in peripheral vascular resistance, in order to restore normal systemic blood pressure values, but also a series of processes that lead to pulmonary interstitial 
fibrosis, endothelial dysfunction, myocardial hypertrophy and a global pro-inflammatory and pro-coagulative state [45].

On the other hand, the ACE2 enzyme physiologically counteracts the activity of $\mathrm{ACE}$, converting Ang II into angiotensin (1-7). Angiotensin (1-7) interacts with Ang II receptor type 2 ( $\mathrm{AT}_{2}$ receptor) and Mas receptor, promoting biological effects opposite to Ang II: it decreases peripheral vascular resistance and reduces inflammation and fibrotic processes [46].

As previously discussed, SARS-CoV-2 binds to ACE2 through its spike proteins and alters its function, favoring accumulation of Ang II with harmful consequences [47].

Interestingly, vitamin D increases the expression of ACE2 in several tissues, thus restoring a physiological ACE2/ACE ratio that can be protective against virus-induced alterations (decreased surfactant production and increased lung Ang II concentrations with damage to blood vessels and parenchyma) [48].

\section{Innate Immunity and Vitamin D}

The precise mechanisms by which SARS-CoV-2 stimulates the innate immune response have not yet been precisely delineated. However, it is thought that the virus interacts with membrane-bound Toll-like receptors (TLRs), in particular with TLR-2 and TLR-4, expressed on the surface of monocytes/macrophages and dendritic cells [49,50]. TLRs expressed on the membrane of the endoplasmic reticulum, such as TLR-7 and TLR-9, seem less important for SARS-CoV-2 invasion, as supported by the failure of the use of hydroxychloroquine in both prophylaxis and treatment of COVID-19. In fact, this antimalarial drug is thought to act on these TLRs, but it proved ineffective, despite widespread use in the first pandemic wave $[51,52]$.

TLR-2 and -4 stimulation activates the production of several pro-inflammatory cytokines, such IL-1, IL-6, TNF- $\alpha$ together with chemokines (IL-8 for neutrophils recruitment) and endothelial adhesion molecules [53]. Moreover, TLR-4 over-stimulation by the virus is responsible for Nod-like receptor protein 3 (NLRP3) inflammasome activation, that causes prolonged and exaggerated production of the aforementioned cytokines [54]. The pathological consequence is the dramatic aforementioned "cytokine storm" with systemic hyperinflammation [33].

SARS-CoV-2 is also able to dysregulate this autophagy, a complex intracellular defense mechanism that eliminates cytoplasmatic components damaged by viruses, bacteria and parasites thanks to the formation of double-membrane vesicles (autophagosomes) which merge with lysosomes to be degraded and recycled [55]. The non-structural protein 6 of SARS-CoV-2 interferes with autophagosome formation, compromising the fusion with lysosomes. Moreover, the virus dysregulates pivotal components of the interferon pathway, avoids the activation of the stimulator of interferon genes (STING) and critically reduces type I interferon production [56-58]. In contrast, calcitriol stimulates autophagy machinery, downregulating inhibitors (mTOR pathway) and stimulating activator factors (Beclin 1 and PI3KC3) [59].

Both monocytes and macrophages express VDR and it has been known for a long time that calcitriol increases the expression of anti-inflammatory IL-10 and reduces proinflammatory cytokines release by activated macrophages, such as IL-1 $\beta$, IL-6, TNF- $\alpha$ (Figure 1) [60,61]. On the other side, VDR expression on myeloid cells is downregulated by inflammation [62]. Vitamin D also exerts antiviral activity, inducing the expression by monocytes, macrophages, neutrophils and human airway epithelial cells of cathelicidin [63-65]. The LL-37 peptide fragment of cathelicidin destroys viral envelopes, as in the case of influenza virus or rhinovirus infections (Figure 1), thus reinforcing defenses against SARS-CoV-2 [66]. 


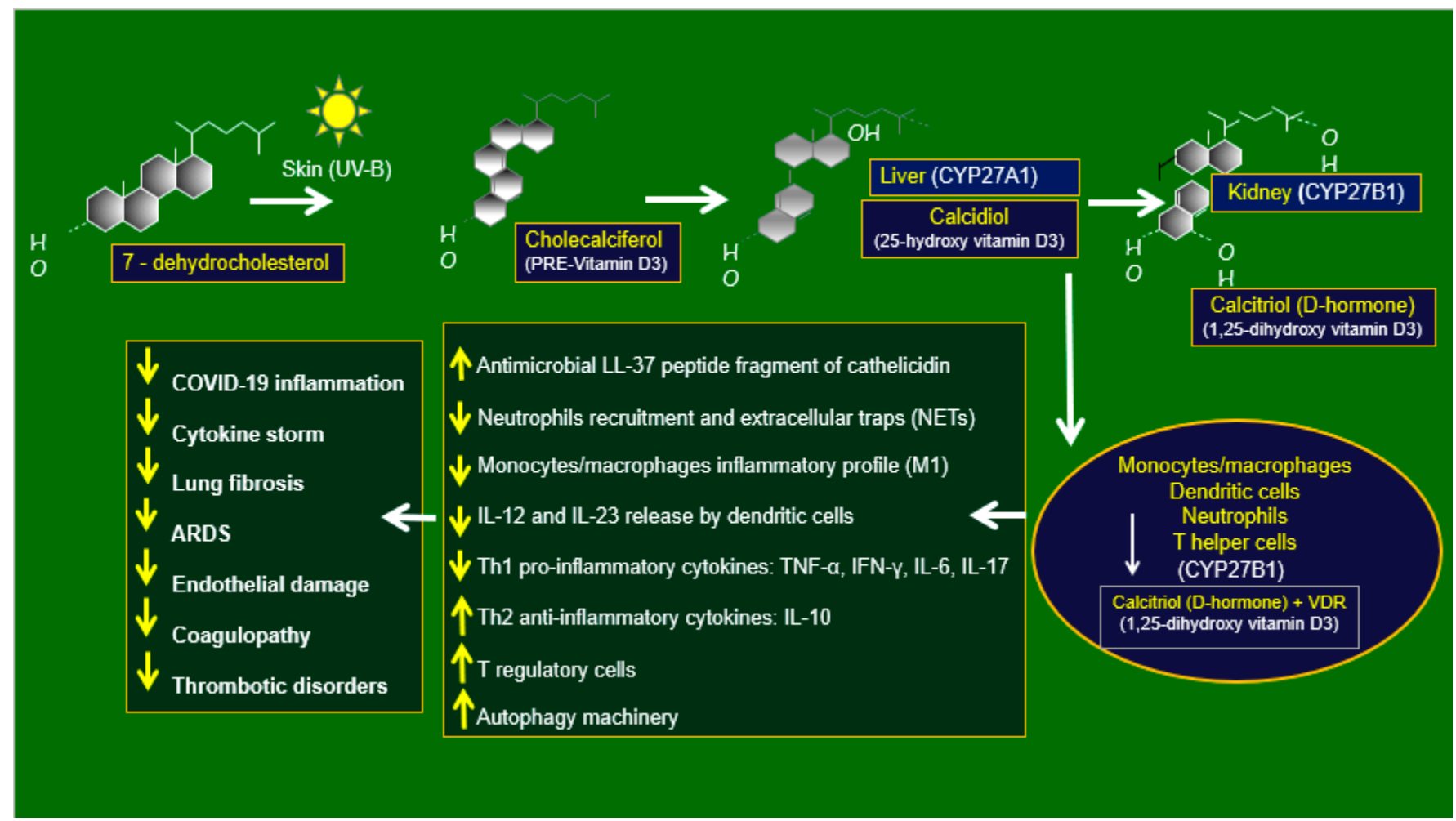

Figure 1. Vitamin D effects on immune system in course of COVID-19. ARDS: acute respiratory distress syndrome; IFN- $\gamma$ : interferon gamma; IL-6: interleukin 6; IL-10: interleukin 10; IL-12: interleukin 12; IL-17: interleukin 17; IL-23: interleukin 23; NETs: neutrophil extracellular traps; Th1: T helper 1; Th2: T helper 2; TNF- $\alpha$ : tumor necrosis factor $\alpha$; UV-B: ultraviolet B.

Neutrophils, recruited by IL-8, infiltrate affected tissues, in particular in the lungs, releasing extracellular traps (NETs), a network of nuclear material that binds pathogens in order to destroy them [67]. Unfortunately, NETs are not able to stop SARS-CoV-2 replication and damage, and they also promote lung inflammation [68].

Of note, an in vivo animal model confirmed the anti-inflammatory properties of vitamin D, also inhibiting the dysregulated release of NETs by neutrophils (Figure 1) [69].

At last, the role of other players of innate immunity in the course of COVID-19, such as dendritic cells and natural killer cells, is still under investigation [70,71]. Interestingly, vitamin D downregulates the production of IL-12 and IL-23 by dendritic cells [72] and serum 25(OH)D concentration lower than $20 \mathrm{ng} / \mathrm{mL}$ have been recently associated with mild reduction of circulating natural killer cells (less than 100 cells $/ \mu \mathrm{L}$ ) in a cohort of patients suffering from COVID-19 pneumonia (Figure 1) [73]. The clinical significance of this observation is currently under investigation.

\section{Adaptive Immunity and Vitamin D}

T cells activation (both CD4+ and CD8+) is deeply impaired in the course of COVID-19 [74]. Lymphopenia is a common condition: SARS-CoV-2 can enter T cells through surface receptors, such as CD26 and CD147, but it is not yet clear whether the virus has a direct cytopathic effect or causes shedding of infected T cell lymphocytes [32].

Moreover, $\mathrm{T}$ regulatory ( $\mathrm{T}$ reg) cells are reduced, thus promoting the development of the dysregulated inflammatory immune response [75]. Calcitriol inhibits pro-inflammatory cytokines production of CD4+ T helper (Th) 1, Th9 and Th17 cells and induces IL-10 by T reg cells, with an overall anti-inflammatory function (Figure 1) [76].

B cells production is stimulated by viral nucleocapsid and spikes proteins, and neutralizing immunoglobulin M (IgM) appear in the serum after 4-8 days since the onset of COVID-19 symptoms [77]. 
Seroconversion of IgM into IgG occurs within two weeks of infection and antibodies serum levels are sustained by increased concentration of circulating $\mathrm{T}$ follicular helper cells $[78,79]$. Calcitriol displays less-pronounced biological activity towards B cells, at least in humans, but again enhances IL-10 production from them [80].

No data are available on the relationship between serum $25(\mathrm{OH}) \mathrm{D}$ values and $\mathrm{T}$ follicular helper cells.

\section{Specific COVID-19 Features and Vitamin D}

Beyond the immunological mechanisms of SARS-CoV-2 infection, vitamin D can interfere with other two main clinical features of severe COVID-19: acute respiratory distress syndrome (ARDS) and coagulopathy.

ARDS is the final result of intense lung inflammation, impaired surfactant production, interstitial fibrosis and coagulation disorders [81]. Of note, VDR gene expression was found to be significantly reduced in the respiratory cells of the bronchoalveolar lavage fluid of COVID-19 patients [82]. In lung epithelial cells, VDR stimulation counteracts acute injury, blocking angiopoietin-2-Tie-2-myosin light chain kinase cascade and the renin-angiotensin system [83]. Moreover, calcitriol is able to downregulate pulmonary inflammation and increases both cathelicidin, with antiviral properties, and surfactant synthesis, thus reducing the alveolar surface tension in the affected lungs (Figure 1) [84,85]. In addition, 25(OH)D deficiency has been associated with severe lung involvement in the course of COVID-19, but further data are required to confirm this observation [41].

Endothelial dysfunction and coagulopathy are two factors that are closely interconnected [86]. ACE-2 is highly expressed by endothelial cells so SARS-CoV-2 shows a high tropism for vessel walls. An in vitro study has demonstrated that the virus impairs endothelial junction proteins, dysregulating the expression of VE-cadherin, JAM-A, Connexin-43 and PECAM-1 [87].

Therefore, the endothelial damage caused by SARS-CoV-2 promotes platelet aggregation as a consequence of the massive exposition of tissue factor and increased levels of von Willebrand factor antigen $[88,89]$. The concomitant dysregulation of the fibrinolytic system, due to abundant circulating plasminogen activator inhibitor 1, reinforces the pro-coagulative state with both arterial and venous thrombotic events [90,91].

Thrombotic microangiopathy secondary to viral infection is histologically characterized by the accumulation of CD4+ T lymphocytes around small vessels, with activation of local megakaryocytes, platelet aggregation, deposition of fibrin and formation of clots [92]. Vitamin D acts on both endothelial dysfunction and coagulopathy. In fact, calcitriol downregulates $\mathrm{NK}-\mathrm{kB}$, whose activation reinforces an inflammatory response, reactive oxygen species formation and intercellular adhesion molecules (Figure 1) [93].

Calcitriol also upregulates thrombomodulin expression and downregulates tissuefactor activation, with a final anticoagulant effect [94]. Low levels of 25(OH)D have been associated to an increased serum concentration of D-dimer, a fibrin degradation product, and a higher risk of both thrombotic events and disseminated intravascular coagulation (Figure 1) [95].

\section{COVID-19 and Vitamin D Supplementation}

Despite the above-reported interactions of vitamin D with COVID-19 pathogenesis and clinical manifestations, a few authors suggested that deficient/insufficient serum concentrations of $25(\mathrm{OH}) \mathrm{D}$ could simply reflect the systemic inflammation induced by the disease [96], but that suggestion is not in line with the evidence from recent RCTs regarding the effects of vitamin D supplementation in the course of COVID-19 [12-17].

In fact, the randomized, placebo-controlled, SHADE study (short term, high-dose vitamin D supplementation for COVID-19 disease) has demonstrated that the administration of cholecalciferol $60.000 \mathrm{IU} /$ day for seven days was able to negativize SARS-CoV-2 RNA nasopharyngeal swab faster than the control group in case of mild or asymptomatic disease, 
after reaching serum $25(\mathrm{OH}) \mathrm{D}$ concentrations $>50 \mathrm{ng} / \mathrm{mL}$ [12]. Authors suggested an early viral clearance exerted by vitamin D to explain these clinical observations [12].

Similarly, a randomized open-label study confirmed that $60.000 \mathrm{IU} /$ day of vitamin $\mathrm{D}$ for eight or ten days in addition to standard therapies significantly reduced markers of inflammation (C-reactive protein, IL-6, ferritin, neutrophils/lymphocytes ratio) in a cohort of hospitalized COVID-19 patients, obtaining efficient final serum 25(OH)D concentrations between 80 and $100 \mathrm{ng} / \mathrm{mL}$ [13].

The reduction of neutrophils/lymphocytes ratio (NLR) was confirmed by a further placebo-controlled, double-blinded RCT with oral supplementation of vitamin $\mathrm{D}_{3}$ (3000-6000 IU/die for 30 days) [14]. The improvement of NLR correlated significantly with a reduction of intensive care unit admission and mortality rates, as already reported by another randomized, open-label study [14,15].

Once again, an open-label RCT that employed a two-week $5000 \mathrm{IU} /$ day cholecalciferol regimen versus $1000 \mathrm{IU} /$ day regimen in a mixed cohort of COVID-19 inpatients and outpatients, reconfirmed a reduction in inflammatory variables (IL-6) and faster improvement in some clinical symptoms (cough and ageusia) [16].

Another open-label study that investigated calcitriol supplementation in COVID-19 patients ( $0.5 \mathrm{mcg}$ daily for 14 days in a hospital setting) showed significant improvement of arterial oxygen saturation/inspired fraction of oxygen ratio $\left(\mathrm{SaO}_{2} / \mathrm{FiO}_{2}\right.$ ratio) in treated patients [17].

At last, it is useful to remember that serum $25(\mathrm{OH}) \mathrm{D}$ concentrations undergo circannual variations due to different solar light exposure (UV) in different countries (seasonal and geographical differences) causing inadequate vitamin D status over many months of the year [97-99]. Therefore, serum 25(OH)D levels at least $\geq 30 \mathrm{ng} / \mathrm{mL}$ seem to reduce the mortality risk for COVID-19 [100], although serum 25(OH)D levels $>50 \mathrm{ng} / \mathrm{mL}$ have also been identified as protective for worst-case scenarios with many risk factors for a lethal outcome [101,102].

These observations match with the optimal target of 25(OH)D serum concentrations between 40 and $80 \mathrm{ng} / \mathrm{mL}$ suggested since the first months of the pandemic [11].

\section{Conclusions}

The most recent available evidence suggests that in the presence of deficiency, vitamin D supplementation allowing serum 25(OH)D values of 40 to $80 \mathrm{ng} / \mathrm{mL}$ to be achieved is effective in reducing the severity of SARS-CoV-2 infection through effects on both innate and acquired immunity.

Ensuring adequate vitamin D provision should, therefore, be considered as an adjunctive measure for the management of COVID-19 risks and of COVID-19 patients, in addition to the standard protective and therapeutic measures in use, including large-scale vaccination plans, new antiviral drugs, glucocorticoids, anticoagulants and biological therapies against pleiotropic pro-inflammatory cytokines. Further RCTs are ongoing in order to confirm the earliest encouraging evidence regarding the effects of exogenous administration of vitamin D in COVID patients.

Author Contributions: E.G. and M.C. conceptualized the argument of the review, collected the data and wrote the manuscript. S.P. and S.S. reviewed the manuscript for important intellectual content. All authors agreed to the content of the manuscript and are accountable for all aspects of accuracy and integrity. All authors have read and agreed to the published version of the manuscript.

Funding: This research received no external funding.

Acknowledgments: E.G., S.P. and M.C. are members of the European Alliance of Associations for Rheumatology (EULAR) Study Group on Neuroendocrine Immunology of Rheumatic Diseases (NEIRD). We acknowledge Sara De Gregorio for her collaboration in picture presentation.

Conflicts of Interest: The authors declare no conflict of interest. 


\section{References}

1. Martens, P.-J.; Gysemans, C.; Verstuyf, A.; Mathieu, C. Vitamin D’s Effect on Immune Function. Nutrients 2020, 12, 1248. [CrossRef] [PubMed]

2. Trombetta, A.C.; Meroni, M.; Cutolo, M. Steroids and Autoimmunity. Front. Horm. Res. 2017, 48, 121-132.

3. Greiller, C.L.; Martineau, A.R. Modulation of the immune response to respiratory viruses by vitamin D. Nutrients 2015, 7, 4240-4270. [CrossRef]

4. Liu, P.T.; Stenger, S.; Li, H.; Wenzel, L.; Tan, B.H.; Krutzik, S.R.; Ochoa, M.T.; Schauber, J.; Wu, K.; Meinken, C.; et al. Toll-like receptor triggering of a vitamin D-mediated human antimicrobial response. Science 2006, 24, 1770-1773. [CrossRef] [PubMed]

5. Cutolo, M.; Otsa, K. Review: Vitamin D, immunity and lupus. Lupus 2008, 17, 6-10. [CrossRef] [PubMed]

6. Cutolo, M.; Otsa, K.; Paolino, S.; Yprus, M.; Veldi, T.; Seriolo, B. Vitamin D involvement in rheumatoid arthritis and systemic lupus erythematosus. Ann. Rheum. Dis. 2009, 68, 446-447. [CrossRef] [PubMed]

7. Cutolo, M. Vitamin D and autoimmune rheumatic diseases. Rheumatology 2009, 48, 210-212. [CrossRef] [PubMed]

8. Cutolo, M.; Plebani, M.; Shoenfeld, Y.; Adorini, L.; Tincani, A. Vitamin D endocrine system and the immune response in rheumatic diseases. Vitam. Horm. 2011, 86, 327-351. [CrossRef]

9. Cutolo, M. Further emergent evidence for the vitamin D endocrine system involvement in autoimmune rheumatic disease risk and prognosis. Ann. Rheum. Dis. 2013, 72, 473-475. [CrossRef]

10. Cutolo, M.; Pizzorni, C.; Sulli, A. Vitamin D endocrine system involvement in autoimmune rheumatic diseases. Autoimmun. Rev. 2011, 11, 84-87. [CrossRef] [PubMed]

11. Cutolo, M.; Paolino, S.; Smith, V. Evidences for a protective role of vitamin D in COVID-19. RMD Open. 2020, 6, e001454. [CrossRef] [PubMed]

12. Rastogi, A.; Bhansali, A.; Khare, N.; Suri, V.; Yaddanapudi, N.; Sachdeva, N.; Puri, G.D.; Malhotra, P. Short term, high-dose vitamin D supplementation for COVID-19 disease: A randomised, placebo-controlled, study (SHADE study). Postgrad. Med. J. 2020, 2020, 139065. [CrossRef]

13. Lakkireddy, M.; Gadiga, S.G.; Malathi, R.D.; Karra, M.L.; Raju ISSVPM, R.; Ragini; Chinapaka, S.; Baba, K.S.S.S.; Kandakatla, M. Impact of daily high dose oral vitamin D therapy on the inflammatory markers in patients with COVID 19 disease. Sci. Rep. 2021, 11, 10641. [CrossRef]

14. Maghbooli, Z.; Sahraian, M.A.; Jamalimoghadamsiahkali, S.; Asadi, A.; Zarei, A.; Zendehdel, A.; Varzandi, T.; Mohammadnabi, S.; Alijani, N.; Karimi, M.; et al. Treatment With 25-Hydroxyvitamin $\mathrm{D}_{3}$ (Calcifediol) Is Associated with a Reduction in the Blood Neutrophil-to-Lymphocyte Ratio Marker of Disease Severity in Hospitalized Patients With COVID-19: A Pilot Multicenter, Randomized, Placebo-Controlled, Double-Blinded Clinical Trial. Endocr. Pract. 2021, 27, P1242-P1251. [CrossRef]

15. Entrenas Castillo, M.; Entrenas Costa, L.M.; Vaquero Barrios, J.M.; Alcalá Díaz, J.F.; López Miranda, J.; Bouillon, R.; Quesada Gomez, J.M.Q. Effect of calcifediol treatment and best available therapy versus best available therapy on intensive care unit admission and mortality among patients hospitalized for COVID-19: A pilot randomized clinical study. J. Steroid Biochem. Mol. Biol. 2020, 203, 105751. [CrossRef]

16. Sabico, S.; Enani, M.A.; Sheshah, E.; Aljohani, N.J.; Aldisi, D.A.; Alotaibi, N.H.; Alshingetti, N.; Alomar, S.Y.; Alnaami, A.M.; Amer, O.E. Effects of a 2-Week 5000 IU versus 1000 IU Vitamin D3 Supplementation on Recovery of Symptoms in Patients with Mild to Moderate Covid-19: A Randomized Clinical Trial. Nutrients 2021, 13, 2170. [CrossRef] [PubMed]

17. Elamir, Y.M.; Amir, H.; Lim, S.; Rana, Y.P.; Lopez, C.G.; Feliciano, N.V.; Omar, A.; Grist, W.P.; Via, M.A. A randomized pilot study using calcitriol in hospitalized COVID-19 patients. Bone 2021, 154, 116175. [CrossRef] [PubMed]

18. Borel, P.; Caillaud, D.; Cano, N.J. Vitamin D bioavailability: State of the art. Crit. Rev. Food Sci. Nutr. 2015, 55, 1193-1205. [CrossRef]

19. Lips, P. Vitamin D physiology. Prog. Biophys. Mol. Biol. 2006, 92, 4-8. [CrossRef] [PubMed]

20. Jassil, N.K.; Sharma, A.; Bikle, D.; Wang, X. Vitamin d binding protein and 25-hydroxyvitamin d levels: Emerging clinical applications. Endocr. Pract. 2017, 23, 605-613. [CrossRef] [PubMed]

21. Hewison, M. An update on vitamin D and human immunity. Clin. Endocrinol. 2012, 76, 315-325. [CrossRef] [PubMed]

22. Cutolo, M.; Paolino, S.; Sulli, A.; Smith, V.; Pizzorni, C.; Seriolo, B. Vitamin D, steroid hormones, and autoimmunity. Ann. N. Y. Acad. Sci. 2014, 1317, 39-46. [CrossRef] [PubMed]

23. Cianferotti, L.; Bertoldo, F.; Bischoff-Ferrari, H.A.; Bruyere, O.; Cooper, C.; Cutolo, M.; Kanis, J.A.; Kaufman, J.-M.; Reginster, J.-Y.; Rizzoli, R.; et al. Vitamin D supplementation in the prevention and management of major chronic diseases not related to mineral homeostasis in adults: Research for evidence and a scientific statement from the European society for clinical and economic aspects of osteoporosis and osteoarthritis (ESCEO). Endocrine 2017, 56, 245-261. [CrossRef] [PubMed]

24. Carlberg, C.; Molnár, F. Vitamin D receptor signaling and its therapeutic implications: Genome-wide and structural view. Can. J. Physiol. Pharmacol. 2015, 93, 311-318. [CrossRef] [PubMed]

25. Boland, R.L. VDR activation of intracellular signaling pathways in skeletal muscle. Mol. Cell. Endocrinol. 2011, 347, 11-16. [CrossRef]

26. Veldurthy, V.; Wei, R.; Campbell, M.; Lupicki, K.; Dhawan, P.; Christakos, S. 25-Hydroxyvitamin D $24-\mathrm{H}_{3}$ droxylase: A Key Regulator of 1,25(OH) ${ }_{2} \mathrm{D}_{3}$ Catabolism and Calcium Homeostasis. Vitam. Horm. 2016, 100, 137-150. [CrossRef] [PubMed]

27. Chen, Y.; Liu, Q.; Guo, D. Emerging coronaviruses: Genome structure, replication, and pathogenesis. J. Med. Virol. 2020, 92, 418-423, Erratum in J. Med. Virol. 2020, 92, 2249. [CrossRef] 
28. Song, W.; Gui, M.; Wang, X.; Xiang, Y. Cryo-EM structure of the SARS coronavirus spike glycoprotein in complex with its host cell receptor ACE2. PLoS Pathog. 2018, 14, e1007236. [CrossRef]

29. Beyerstedt, S.; Casaro, E.B.; Rangel, É.B. COVID-19: Angiotensin-converting enzyme 2 (ACE2) expression and tissue susceptibility to SARS-CoV-2 infection. Eur. J. Clin. Microbiol. Infect. Dis. 2021, 40, 905-919. [CrossRef]

30. Parasher, A. COVID-19: Current understanding of its Pathophysiology, Clinical presentation and Treatment. Postgrad. Med. J. 2021, 97, 312-320. [CrossRef]

31. Siddiqi, H.K.; Mehra, M.R. COVID-19 illness in native and immunosuppressed states: A clinical-therapeutic staging proposal. J. Heart Lung Transpl. 2020, 39, 405-407. [CrossRef]

32. Sokolowska, M.; Lukasik, Z.M.; Agache, I.; Akdis, C.A.; Akdis, D.; Akdis, M.; Barcik, W.; Brough, H.A.; Eiwegger, T.; Eljaszewicz, A.; et al. Immunology of COVID-19: Mechanisms, clinical outcome, diagnostics, and perspectives-A report of the European Academy of Allergy and Clinical Immunology (EAACI). Allergy 2020, 75, 2445-2476. [CrossRef]

33. Fara, A.; Mitrev, Z.; Rosalia, R.A.; Assas, B.M. Cytokine storm and COVID-19: A chronicle of pro-inflammatory cytokines. Open Biol. 2020, 10, 200160. [CrossRef] [PubMed]

34. D'Avolio, A.; Avataneo, V.; Manca, A.; Cusato, J.; De Nicolò, A.; Lucchini, R.; Keller, F.; Cantù, M. 25-Hydroxyvitamin D Concentrations Are Lower in Patients with Positive PCR for SARS-CoV-2. Nutrients 2020, 12, 1359. [CrossRef] [PubMed]

35. Mercola, J.; Grant, W.B.; Wagner, C.L. Evidence Regarding Vitamin D and Risk of COVID-19 and Its Severity. Nutrients 2020, 12, 3361. [CrossRef] [PubMed]

36. Kaufman, H.W.; Niles, J.K.; Kroll, M.H.; Bi, C.; Holick, M.F. SARS-CoV-2 positivity rates associated with circulating 25-hydroxyvitamin D levels. PLoS ONE 2020, 15, e0239252. [CrossRef] [PubMed]

37. Hastie, C.E.; Mackay, D.F.; Ho, F.; Celis-Morales, C.A.; Katikireddi, S.V.; Niedzwiedz, C.L.; Jani, B.D.; Welsh, P.; Mair, F.S.; Gray, S.R.; et al. Vitamin D concentrations and COVID-19 infection in UK Biobank. Diabetes Metab. Syndr. 2020, 14, 561-565. [CrossRef] [PubMed]

38. Akbar, M.R.; Wibowo, A.; Pranata, R.; Setiabudiawan, B. Low Serum 25-hydroxyvitamin D (Vitamin D) Level Is Associated with Susceptibility to COVID-19, Severity, and Mortality: A Systematic Review and Meta-Analysis. Front. Nutr. 2021, 8, 660420. [CrossRef]

39. Dramé, M.; Cofais, C.; Hentzien, M.; Proye, E.; Coulibaly, P.S.; Demoustier-Tampère, D.; Destailleur, M.-H.; Lotin, M.; Cantagrit, E.; Cebille, A.; et al. Relation between Vitamin D and COVID-19 in Aged People: A Systematic Review. Nutrients 2021, 13, 1339. [CrossRef]

40. Wang, Z.; Joshi, A.; Leopold, K.; Jackson, S.; Christensen, S.; Nayfeh, T.; Mohammed, K.; Creo, A.; Tebben, P.; Kumar, S. Association of vitamin D deficiency with COVID-19 infection severity: Systematic review and meta-analysis. Clin. Endocrinol. (Oxf.) 2021, 10, 14540. [CrossRef]

41. Sulli, A.; Gotelli, E.; Casabella, A.; Paolino, S.; Pizzorni, C.; Alessandri, E.; Grosso, M.; Ferone, D.; Smith, V.; Cutolo, M. Vitamin D and Lung Outcomes in Elderly COVID-19 Patients. Nutrients 2021, 13, 717. [CrossRef]

42. Ramirez-Sandoval, J.C.; Castillos-Ávalos, V.J.; Paz-Cortés, A.; Santillan-Ceron, A.; Hernandez-Jimenez, S.; Mehta, R.; CorreaRotter, R. Very Low Vitamin D Levels are a Strong Independent Predictor of Mortality in Hospitalized Patients with Severe COVID-19. Arch. Med. Res. 2021, 15, S0188-4409. [CrossRef]

43. Bychinin, M.V.; Klypa, T.V.; Mandel, I.A.; Andreichenko, S.A.; Baklaushev, V.P.; Yusubalieva, G.M.; A Kolyshkina, N.; Troitsky, A.V. Low Circulating Vitamin D in Intensive Care Unit-Admitted COVID-19 Patients as a Predictor of Negative Outcomes. J. Nutr. 2021, 151, 2199-2205. [CrossRef] [PubMed]

44. Tikellis, C.; Thomas, M.C. Angiotensin-Converting Enzyme 2 (ACE2) Is a Key Modulator of the Renin Angiotensin System in Health and Disease. Int. J. Pept. 2012, 2012, 256294. [CrossRef] [PubMed]

45. Kuba, K.; Imai, Y.; Penninger, J.M. Multiple functions of angiotensin-converting enzyme 2 and its relevance in cardiovascular diseases. Circ. J. 2013, 77, 301-308. [CrossRef] [PubMed]

46. Simões e Silva, A.C.; Silveira, K.D.; Ferreira, A.J.; Teixeira, M.M. ACE2, angiotensin-(1-7) and Mas receptor axis in inflammation and fibrosis. Br. J. Pharm. 2013, 169, 477-492. [CrossRef]

47. Xiao, L.; Sakagami, H.; Miwa, N. ACE2: The key Molecule for Understanding the Pathophysiology of Severe and Critical Conditions of COVID-19: Demon or Angel? Viruses 2020, 12, 491. [CrossRef]

48. Cui, C.; Xu, P.; Li, G.; Qiao, Y.; Han, W.; Geng, C.; Liao, D.; Yang, M.; Chen, D.; Jiang, P. Vitamin D receptor activation regulates microglia polarization and oxidative stress in spontaneously hypertensive rats and angiotensin II-exposed microglial cells: Role of renin-angiotensin system. Redox Biol. 2019, 26, 101295. [CrossRef]

49. Aboudounya, M.M.; Heads, R.J. COVID-19 and Toll-Like Receptor 4 (TLR4): SARS-CoV-2 May Bind and Activate TLR4 to Increase ACE2 Expression, Facilitating Entry and Causing Hyperinflammation. Mediat. Inflamm. 2021, 2021, 8874339. [CrossRef]

50. Khan, S.; Shafiei, M.; Longoria, C.; Schoggins, J.W.; Savani, R.; Zaki, H. SARS-CoV-2 spike protein induces inflammation via TLR2-dependent activation of the NF-kB pathway. eLife 2021, 10, e68563. [CrossRef]

51. Lewis, K.; Chaudhuri, D.; Alshamsi, F.; Carayannopoulos, L.; Dearness, K.; Chagla, Z.; Alhazzani, W. GUIDE Group. The efficacy and safety of hydroxychloroquine for COVID-19 prophylaxis: A systematic review and meta-analysis of randomized trials. PLoS ONE 2021, 16, e0244778. [CrossRef] 
52. Fiolet, T.; Guihur, A.; Rebeaud, M.E.; Mulot, M.; Peiffer-Smadja, N.; Mahamat-Saleh, Y. Effect of hydroxychloroquine with or without azithromycin on the mortality of coronavirus disease 2019 (COVID-19) patients: A systematic review and meta-analysis. Clin. Microbiol. Infect. 2021, 27, 19-27. [CrossRef]

53. Joosten, L.A.; Abdollahi-Roodsaz, S.; Dinarello, C.A.; O’Neill, L.; Netea, M.G. Toll-like receptors and chronic inflammation in rheumatic diseases: New developments. Nat. Rev. Rheumatol. 2016, 12, 344-357. [CrossRef]

54. van den Berg, D.F.; Te Velde, A.A. Severe COVID-19: NLRP3 Inflammasome Dysregulated. Front. Immunol. 2020, 11, 1580. [CrossRef] [PubMed]

55. García-Pérez, B.E.; González-Rojas, J.A.; Salazar, M.I.; Torres-Torres, C.; Castrejón-Jiménez, N.S. Taming the Autophagy as a Strategy for Treating COVID-19. Cells 2020, 9, 2679. [CrossRef] [PubMed]

56. Kumar, A.; Kumar, P.; Saumya, K.U.; Giri, R. Investigating the conformational dynamics of SARS-CoV-2 NSP6 protein with emphasis on non-transmembrane 91-112 \& 231-290 regions. Microb. Pathog. 2021, 161, 105236. [CrossRef] [PubMed]

57. Han, L.; Zhuang, M.W.; Deng, J.; Zheng, Y.; Zhang, J.; Nan, M.; Zhang, X.; Gao, C.; Wang, P. SARS-CoV-2 ORF9b antagonizes type I and III interferons by targeting multiple components of the RIG-I/MDA-5-MAVS, TLR3-TRIF, and cGAS-STING signaling pathways. J. Med. Virol. 2021, 93, 5376-5389. [CrossRef]

58. Acharya, D.; Liu, G.; Gack, M.U. Dysregulation of type I interferon responses in COVID-19. Nat. Rev. Immunol. 2020, 20, 397-398 [CrossRef] [PubMed]

59. Bilezikian, J.P.; Bikle, D.; Hewison, M.; Lazaretti-Castro, M.; Formenti, A.M.; Gupta, A.; Madhavan, M.V.; Nair, N.; Babalyan, V.; Hutchings, N.; et al. MECHANISMS IN ENDOCRINOLOGY: Vitamin D and COVID-19. Eur. J. Endocrinol. 2020, 183, R133-R147. [CrossRef]

60. Colotta, F.; Jansson, B.; Bonelli, F. Modulation of inflammatory and immune responses by vitamin D. J. Autoimmun. 2017, 85, 78-97. [CrossRef]

61. Villaggio, B.; Soldano, S.; Cutolo, M. 1,25-dihydroxyvitamin D3 downregulates aromatase expression and inflammatory cytokines in human macrophages. Clin. Exp. Rheumatol. 2012, 30, 934-938, Erratum in J. Med. Virol. 2012, 17, 23253631. [CrossRef] [PubMed]

62. Sun, J.; Liu, C.; Zhang, S.; Yi, B.; Gui, M.; Zhang, W.; Li, Y.C.; Zhang, H. Vitamin D receptor expression in peripheral blood mononuclear cells is inversely associated with disease activity and inflammation in lupus patients. Clin. Rheumatol. 2019, 38, 2509-2518. [CrossRef]

63. Liu, P.T.; Stenger, S.; Tang, D.H.; Modlin, R.L. Cutting edge: Vitamin D-mediated human antimicrobial activity against Mycobacterium tuberculosis is dependent on the induction of cathelicidin. J. Immunol. 2007, 179, 2060-2063. [CrossRef] [PubMed]

64. Gombart, A.F.; Borregaard, N.; Koeffler, H.P. Human cathelicidin antimicrobial peptide (CAMP) gene is a direct target of the vitamin D receptor and is strongly up-regulated in myeloid cells by 1,25-dihydroxyvitamin D3. FASEB J. 2005, 19, 1067-1077. [CrossRef] [PubMed]

65. Wei, R.; Dhawan, P.; Baiocchi, R.A.; Kim, K.Y.; Christakos, S. PU.1 and epigenetic signals modulate 1,25-dihydroxyvitamin D 3 and $\mathrm{C} / \mathrm{EBP} \alpha$ regulation of the human cathelicidin antimicrobial peptide gene in lung epithelial cells. J. Cell. Physiol. 2019, 234, 10345-10359. [CrossRef] [PubMed]

66. Brice, D.C.; Diamond, G. Antiviral Activities of Human Host Defense Peptides. Curr. Med. Chem. 2020, 27, 1420-1443. [CrossRef] [PubMed]

67. Yaqinuddin, A.; Kvietys, P.; Kashir, J. COVID-19: Role of neutrophil extracellular traps in acute lung injury. Respir. Investig. 2020, 58, 419-420. [CrossRef] [PubMed]

68. Middleton, E.A.; He, X.Y.; Denorme, F.; Campbell, R.A.; Ng, D.; Salvatore, S.P.; Mostyka, M.; Baxter-Stoltzfus, A.; Borczuk, A.C.; Loda, M.; et al. Neutrophil extracellular traps contribute to immunothrombosis in COVID-19 acute respiratory distress syndrome. Blood 2020, 136, 1169-1179. [CrossRef]

69. Chen, C.; Weng, H.; Zhang, X.; Wang, S.; Lu, C.; Jin, H.; Chen, S.; Liu, Y.; Sheng, A.; Sun, Y. Low-Dose Vitamin D Protects Hyperoxia-Induced Bronchopulmonary Dysplasia by Inhibiting Neutrophil Extracellular Traps. Front. Pediatr. 2020, 8, 335. [CrossRef]

70. Borges, R.C.; Hohmann, M.S.; Borghi, S.M. Dendritic cells in COVID-19 immunopathogenesis: Insights for a possible role in determining disease outcome. Int. Rev. Immunol. 2021, 40, 108-125. [CrossRef]

71. van Eeden, C.; Khan, L.; Osman, M.S.; Cohen Tervaert, J.W. Natural Killer Cell Dysfunction and Its Role in COVID-19. Int. J. Mol. Sci. 2020, 21, 6351. [CrossRef]

72. Baeke, F.; Takiishi, T.; Korf, H.; Gysemans, C.; Mathieu, C. Vitamin D: Modulator of the immune system. Curr. Opin. Pharmacol. 2010, 10, 482-496. [CrossRef]

73. Vassiliou, A.G.; Jahaj, E.; Pratikaki, M.; Keskinidou, C.; Detsika, M.; Grigoriou, E.; Psarra, K.; Orfanos, S.E.; Tsirogianni, A.; Dimopoulou, I.; et al. Vitamin D deficiency correlates with a reduced number of natural killer cells in intensive care unit (ICU) and non-ICU patients with COVID-19 pneumonia. Hell. J. Cardiol. 2020, 62, 381-383. [CrossRef]

74. Toor, S.M.; Saleh, R.; Sasidharan Nair, V.; Taha, R.Z.; Elkord, E. T-cell responses and therapies against SARS-CoV-2 infection. Immunology 2021, 162, 30-43. [CrossRef] [PubMed]

75. Meckiff, B.J.; Ramírez-Suástegui, C.; Fajardo, V.; Chee, S.J.; Kusnadi, A.; Simon, H.; Eschweiler, S.; Grifoni, A.; Pelosi, E.; Weiskopf, D.; et al. Imbalance of Regulatory and Cytotoxic SARS-CoV-2-Reactive CD4 ${ }^{+}$T Cells in COVID-19. Cell 2020, 183, 1340-1353.e16. [CrossRef] [PubMed] 
76. Cantorna, M.T.; Snyder, L.; Lin, Y.D.; Yang, L. Vitamin D and 1,25(OH)2D regulation of T cells. Nutrients 2015, 7, 3011-3021. [CrossRef]

77. OMurchu, E.; Byrne, P.; Walsh, K.A.; Carty, P.G.; Connolly, M.; De Gascun, C.; Jordan, K.; Keoghan, M.; O’Brien, K.K.; O’Neill, M.; et al. Immune response following infection with SARS-CoV-2 and other coronaviruses: A rapid review. Rev. Med. Virol. 2021, 31, e2162. [CrossRef]

78. Liu, A.; Li, Y.; Peng, J.; Huang, Y.; Xu, D. Antibody responses against SARS-CoV-2 in COVID-19 patients. J. Med. Virol. 2021, 93, 144-148. [CrossRef]

79. Zhang, J.; Wu, Q.; Liu, Z.; Wang, Q.; Wu, J.; Hu, Y.; Bai, T.; Xie, T.; Huang, M.; Wu, T.; et al. Spike-specific circulating T follicular helper cell and cross-neutralizing antibody responses in COVID-19-convalescent individuals. Nat. Microbiol. 2021, 6, 51-58. [CrossRef]

80. Heine, G.; Niesner, U.; Chang, H.D.; Steinmeyer, A.; Zügel, U.; Zuberbier, T.; Radbruch, A.; Worm, M. 1,25-dihydroxyvitamin D(3) promotes IL-10 production in human B cells. Eur. J. Immunol. 2008, 38, 2210-2218. [CrossRef]

81. Thapa, K.; Verma, N.; Singh, T.G.; Kaur Grewal, A.; Kanojia, N.; Rani, L. COVID-19-Associated acute respiratory distress syndrome (CARDS): Mechanistic insights on therapeutic intervention and emerging trends. Int. Immunopharmacol. 2021, 101, 108328. [CrossRef] [PubMed]

82. George, B.; Amjesh, R.; Paul, A.M.; Santhoshkumar, T.R.; Pillai, M.R.; Kumar, R. Evidence of a dysregulated vitamin D endocrine system in SARS-CoV-2 infected patient's lung cells. Sci. Rep. 2021, 11, 8570. [CrossRef] [PubMed]

83. Kong, J.; Zhu, X.; Shi, Y.; Liu, T.; Chen, Y.; Bhan, I.; Zhao, Q.; Thadhani, R.; Li, Y.C. VDR attenuates acute lung injury by blocking Ang-2-Tie-2 pathway and renin-angiotensin system. Mol. Endocrinol. 2013, 27, 2116-2125. [CrossRef] [PubMed]

84. Fakhoury, H.M.A.; Kvietys, P.R.; Shakir, I.; Shams, H.; Grant, W.B.; Alkattan, K. Lung-Centric Inflammation of COVID-19: Potential Modulation by Vitamin, D. Nutrients 2021, 13, 2216. [CrossRef] [PubMed]

85. Phokela, S.S.; Peleg, S.; Moya, F.R.; Alcorn, J.L. Regulation of human pulmonary surfactant protein gene expression by 1alpha,25-dihydroxyvitamin $\mathrm{D}_{3}$. Am. J. Physiol. Lung Cell. Mol. Physiol. 2005, 289, 617-626. [CrossRef]

86. Bonaventura, A.; Vecchié, A.; Dagna, L.; Martinod, K.; Dixon, D.L.; Van Tassell, B.W.; Dentali, F.; Montecucco, F.; Massberg, S.; Levi, M.; et al. Endothelial dysfunction and immunothrombosis as key pathogenic mechanisms in COVID-19. Nat. Rev. Immunol. 2021, 21, 319-329. [CrossRef]

87. Raghavan, S.; Kenchappa, D.B.; Leo, M.D. SARS-CoV-2 Spike Protein Induces Degradation of Junctional Proteins That Maintain Endothelial Barrier Integrity. Front. Cardiovasc. Med. 2021, 8, 687783. [CrossRef]

88. Rosell, A.; Havervall, S.; von Meijenfeldt, F.; Hisada, Y.; Aguilera, K.; Grover, S.P.; Lisman, T.; Mackman, N.; Thålin, C. Patients With COVID-19 Have Elevated Levels of Circulating Extracellular Vesicle Tissue Factor Activity That Is Associated with Severity and Mortality-Brief Report. Arterioscler Thromb. Vasc. Biol. 2021, 41, 878-882. [CrossRef]

89. Mancini, I.; Baronciani, L.; Artoni, A.; Colpani, P.; Biganzoli, M.; Cozzi, G.; Novembrino, C.; Anzoletti, M.B.; De Zan, V.; Pagliari, M.T.; et al. The ADAMTS13-von Willebrand factor axis in COVID-19 patients. J. Thromb. Haemost. 2021, 19, 513-521. [CrossRef]

90. Whyte, C.S.; Morrow, G.B.; Mitchell, J.L.; Chowdary, P.; Mutch, N.J. Fibrinolytic abnormalities in acute respiratory distress syndrome (ARDS) and versatility of thrombolytic drugs to treat COVID-19. J. Thromb. Haemost. 2020, 18, 1548-1555. [CrossRef]

91. Cangemi, R.; Calvieri, C.; Falcone, M.; Cipollone, F.; Ceccarelli, G.; Pignatelli, P.; D’Ardes, D.; Pirro, M.; Alessandri, F.; Lichtner, M.; et al. Comparison of thrombotic events and mortality in patients with community-acquired pneumonia and COVID-19: A multicentre observational study. Thromb. Haemost. 2021. [CrossRef] [PubMed]

92. Belen-Apak, F.B.; Sarıalioğlu, F. Pulmonary intravascular coagulation in COVID-19: Possible pathogenesis and recommendations on anticoagulant/thrombolytic therapy. J. Thromb. Thrombolysis 2020, 50, 278-280. [CrossRef]

93. Zhang, J.; McCullough, P.A.; Tecson, K.M. Vitamin D deficiency in association with endothelial dysfunction: Implications for patients with COVID-19. Rev. Cardiovasc. Med. 2020, 21, 339-344. [CrossRef]

94. Sengupta, T.; Majumder, R.; Majumder, S. Role of vitamin D in treating COVID-19-associated coagulopathy: Problems and perspectives. Mol. Cell. Biochem. 2021, 476, 2421-2427. [CrossRef] [PubMed]

95. Susianti, H.; Wahono, C.S.; Rahman, P.A.; Pratama, M.Z.; Wulanda, I.A.; Hartanti, K.D.; Dewi, E.S.; Handono, K. Low levels of vitamin D were associated with coagulopathy among hospitalized coronavirus disease-19 (COVID-19) patients: A single-centered study in Indonesia. J. Med. Biochem. 2021, 40, 341-350. [CrossRef]

96. Antonelli, M.; Kushner, I. Low Serum Levels of 25-Hydroxyvitamin D Accompany Severe COVID-19 Because it is a Negative Acute Phase Reactant. Am. J. Med. Sci. 2021, 362, 333-335. [CrossRef]

97. Seriolo, B.; Molfetta, L.; Cutolo, M. Seasonal variations in serum levels of 25-hydroxyvitamin D in patients with systemic sclerosis. Clin. Rheumatol. 2011, 30, 445-446. [CrossRef]

98. Cutolo, M.; Soldano, S.; Sulli, A.; Smith, V.; Gotelli, E. Influence of Seasonal Vitamin D Changes on Clinical Manifestations of Rheumatoid Arthritis and Systemic Sclerosis. Front. Immunol. 2021, 12, 683665. [CrossRef]

99. Lips, P.; Cashman, K.D.; Lamberg-Allardt, C.; Bischoff-Ferrari, H.A.; Obermayer-Pietsch, B.; Bianchi, M.L.; Stepan, J.; El-Hajj Fuleihan, G.; Bouillon, R. Current vitamin D status in European and Middle East countries and strategies to prevent vitamin D deficiency: A position statement of the European Calcified Tissue Society. Eur. J. Endocrinol. 2019, 180, P23-P54. [CrossRef] [PubMed]

100. Oristrell, J.; Oliva, J.C.; Casado, E.; Subirana, I.; Domínguez, D.; Toloba, A.; Balado, A.; Grau, M. Vitamin D supplementation and COVID-19 risk: A population-based, cohort study. J. Endocrinol. Investig. 2021, 17, 1-13. [CrossRef] 
101. Borsche, L.; Glauner, B.; von Mendel, J. COVID-19 Mortality Risk Correlates Inversely with Vitamin D3 Status, and a Mortality Rate Close to Zero Could Theoretically Be Achieved at $50 \mathrm{ng} / \mathrm{mL}$ 25(OH)D3: Results of a Systematic Review and Meta-Analysis. Nutrients 2021, 13, 3596. [CrossRef] [PubMed]

102. Cutolo, M.; Smith, V.; Paolino, S. Understanding immune effects of oestrogens to explain the reduced morbidity and mortality in female versus male COVID-19 patients. Comparisons with autoimmunity and vaccination. Clin. Exp. Rheumatol. 2020, 38, 383-386. [PubMed] 